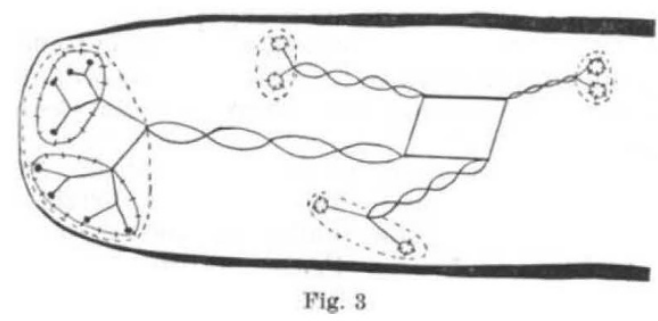

The latter then divide in two, and cross-walls are laid down in parent hypha and clamp connexion. Spindles have not been seen in living material. A study of fixed preparations stained with : $(a)$ hæmatoxylin or (b) Feulgen stain showed: (a) (1) when the grey bodies are not near the clamp connexions, that is, are not approaching or in process of division, they do not stain deeply and can be distinguished clearly from the general cytoplasm only if Light Green is used as a counterstain. Paired granules staining deeply with hæmatoxylin are to be seen in the cytoplasm. Sparrow and Hammond ${ }^{4}$ comment on the frequency of cells showing a correlation between lightly stained nuclei and a large volume of cytoplasmic bodies (Feulgen reaction). (2) When the grey bodies are near clamp connexions which are forming, they stain darkly. They may have a mottled appearance, suggesting that granules are present on their surface. Deeply stained granules are no longer visible in the cytoplasm. (b) (1) The grey bodies are Feulgen-negative and there are pairs of Feulgen-positive granules in the cytoplasm. The grey bodies counter-stain with Fast Green. This indicates the nucleolus in higher plants ${ }^{14}$. (2) Near the time of division, the grey bodies are in part Feulgen-positive, in part stainable with Fast Green. The Feulgen-positive granules are missing from the cytoplasm.

The above observations show that, if the conventional idea of the resting nucleus is accepted, there is extra-nuclear chromatin present in the vegetative cells of Marasmius androsaceus Fr. The fact that the Feulgen-positive cytoplasmic granules are often paired is regarded as evidence in favour of the theory that they represent either the two complete chromatids, or equivalent aggregates of chromatin-containing material from the two chromatids of a chromosome, loosely attached together. The fact that these Feulgen-positive granules are widely distributed in the cytoplasm, yet are drawn towards and finally become closely associated with the Feulgen-negative grey body, at the time of nuclear division, is believed to be strong evidence in favour of a theory that the nucleus in the 'resting' condition consists of a Feulgen-negative shadow nucleus to which the chromosomes or parts thereof are attached by means of threads of variable length, composed of protein molecules (possibly polypeptide in nature). The extensible or retractable nature of the protein chain visualized is such that it would make it possible for the active material in any chromosome to be carried to that part of the cell where its activity is required at any given time. Thus the laying down of new wall material, in the terminal $10-20 \mu$ of the hypha to which growth is confined, would be carried out by the activity of a pair of granules in the tip and remotely controlled only by the shadow nucleus which is situated about $120 \mu$ from the tip and thus well outside the growing region. At the approach of nuclear division, shortening of the molecule chains, by bringing granules and shadow nucleus together, would produce the stainable nuclear entity usually depicted in association with clamp connexions. Fig. 3 is a theoretical diagram illustrating the organisation of a resting nucleus with four chromosomes.

It is hoped that the existence of the molecular chains may be susceptible of proof with the electron microscope, and some preliminary investigations have been carried out on this problem.

${ }^{1}$ Hollande, A. C., Arch. Zool. Exp. et Gén., 83 (Suppl.), 269 (1943), ' Hollande, A. C., and Hollande, G., Arch. Zool. Exp. et GEn., 84 (9),

${ }^{3}$ Drennan, M. R., Clin. Proc., 3 (4), 171 (1944).

4 Sparrow, A. H., and Hammond, M. R., Amer. J. Bot., 34 (8), 439 (1947).

${ }^{5}$ Calvet, F., Siegel, B. M., and Stern, K. G., Nature, 162, 305 (1948).

- Malvesin-Fabre, G., C.R. Soc. Biol., 135, 590 (1941).

${ }^{7}$ Ritchie, D., Bot. Gaz., 109, 521 (1948).

s Macdonald, J. A., Proc. Roy. Soc. Edin. (B) (in the press).

- Macdonald, J. A., Trans. Brit. Mycol. Soc., 31, 92 (1947).

${ }^{10}$ Burch, C. R., and Stock, J. P. P., J. Sci. Instr., 19 (5), 71 (1942).

${ }^{11}$ Gwynne Vaughan, H. C. I., and Barnes, B., "Structure and De. velopment of the Fungi"' (1937).

${ }^{12}$ La Cour, L., Bot. Rev., 8, 241 (1937).

${ }^{13}$ La Cour, L., Bot. Rev., 13, 216 (1947).

${ }^{14}$ Hillary, B. B.. Bot. Gaz., 102, 225 (1941).

\section{A NOTATION FOR THE LEWIS AND LUTHERAN BLOOD-GROUP SYSTEMS}

BY means/of a grant from the World Health Organisation, the following were able to meet to discuss a notation for the Lewis and Lutheran bloodgroup/system: P. H. Andresen, Universitetets Retsmediciniske Institut, Copenhagen; S. T. Callender, the Radcliffe Infirmary, Oxford; R. A. Fisher, Department of Genetics, Cambridge; R. Grubb, Bakteriologiska Institutionen, Lund; W. T. J. Morgan, Biochemical Department, Lister Institute, London; A. E. Mourant, Ministry of Health, Lister Institute, London; M. M. Pickles, Pathological Department, Radcliffe Infirmary, Oxford; R. R. Race, Medical Research Council, Lister Institute, London. The appended report has been prepared.

"For both the Lutheran" and Lewis" blood-group systems the symbols $L_{1}$ and $L_{2}$ have been used ${ }^{3,4}$. The Lewis system is being actively investigated at the present time, and the need for distinctive symbols has become urgent.

In agreeing to use the following notation we are adhering, so far as the genes and genotypes are concerned, to present usage in plant and animal genetics. In human genetics there is as yet no systematized genetical notation in use, though Ford has suggested such a notation for the $A_{1} A_{2} B O$ blood groups ${ }^{6}$. The notations we have chosen conform with that of Ford.

$\begin{array}{lll}\text { System } & \text { Lewis } & \text { Lutheran } \\ \text { Genes } & \text { Lea } & \text { Lua } \\ \text { Genotypes } & \text { Leb } & \text { Lub } \\ & \text { LeaLea } & \text { LuaLua } \\ & \text { LeaLeb } & \text { LuaLub } \\ \text { Phenotypes } & \text { LebLeb } & \text { LubLub } \\ & \text { Le }(a+b-) & \text { Lu(a+) } \\ & \text { Le(a-b+) } & \text { Lu(a-) } \\ \text { Le(a-b-) } & \text { anti-Lua } \\ \text { Antibodies } & \text { anti-Lea } & \end{array}$

No distinction is made between the symbols for the genes and those for the antigens. 
The antibody anti-Lea corresponds to the original ${ }^{2,5}$ anti-Lewis and to the anti- $L_{1}$ of Andresen ${ }^{4}$; and anti- $L e^{b}$ to Andresen's anti- $L_{2}$.

If only one antiserum, anti-Le $e^{a}$, is used the phenotypes which it defines are called $L e(a+)$ and $L e(a-)$.

In the $L u$ system anti- $L u^{a}$ corresponds to the original anti-Lutheran of Callender and Race?. The phenotype $L u(a+)$ thus includes both the phenotypes $L_{1}$ and $L_{2}$ of Mainwaring and Pickles ${ }^{3}$.

These notations can readily be expanded to allow for future developments. For example, in the Le system the known phenotype $L e(a-b-)$ might be shown to be due to a qualitatively different third allele which would be written $L e^{c}$. In the $L u$ system the quantitatively differing $L_{1}$ and $L_{2}$ might become $L u^{a_{1}}$ and $L u^{a_{2}}$.

The duplication of the $S s$ notation with reference to salivary secretion of blood-group substances on one hand and to subgroups of the $M N$ system on the other has been considered, in view of the close connexion of secretion with the $L e$ system $^{7,8,8}$. Since this duplication has not so far caused confusion, it has been decided not to recommend any changes in the use of $S$ and $s$ pending further work on the Le system."

Callender, Race and Paykoc, Brit. Med. J., i1, 83 (1945). Callender and Race, Ann. Eugen., Camb., 13, 102 (1946).

'Mourant, Nature, 158, 237 (1946).

Mainwaring and Pickles, J. Clin. Path., 1, 292 (1948).

- Andresen, Acta Path. Microbiol. Scand., 25, 728 (1948).

- Andresen, Acta Path. Microbiol. Scand., 24, 616 (1947).

'Ford, "Genetics for Medical Students" (London, 1942).

'Grubb, Nature, 162, 933 (1948).

- Grubb and Morgan, Brit. J. Exp. Path. (in the press).

- Race, Sanger, Lawler and Bertinshaw, Brit. J. Exp. Path. (in the press).

$$
316
$$

\section{THE TEACHING OF PHYSICS}

$\mathrm{T}$ HE second conference on the teaching of physics, organised joflaty by the Institute of Physics and the MMatry of Education, was held at the Institu of Physica,/47 Belgrave Square, London, S.W H. Nuiring Hetruary 24-26. Dr. F. C. Toy, prosifent of the Anstitute, in welcoming the members and opening the conference, spoke of the need for producing a broad and cultured outlook, which should develop men who were both good physicists and good citizens.

At the first session, Dr. B. P. Dudding and Mr. C. E. Beynon opened a discussion on "Physics for Part-time Students from Industry". Dr. Dudding said that the present close relations between engineering and physics require that engineers should be trained in the application of scientific method, by courses which present a broad outline of the subject without tò much academic detail. Technical ability is less important than personal qualities of judgment and character, and the ability to analyse problems as they arose. It is only too easy to read one's own convictions into the interpretation of data, and the teaching of basic physics should be done in such a way as to cultivate intellectual honesty.

Mr. Beynon spoke of the need, greater now than in the time between the two World Wars, for more highly trained men in the higher ranks of industry, and suggested that if the present methods of recruitment are unsuitable, better means must be found. The technical colleges of the future should make pure and applied physics major subjects in their courses, training students by doing rather than mere learning, and cultivating a practical as opposed to an abstract academic view of these subjects. Part-time students from industry would work beside full-time students from the universities, and while meeting the needs of both, the technical colleges should develop an individuality of their own, not modelled on either the universities or apprentice schools. Details of a course of training were outlined, and Mr. Beynon suggested that the satisfactory completion of such a course should be recognized by some kind of award which would have a 'hard currency' value in industry.

At the evening session, Mr. C. W. Robson opened a discussion on "National Certificates in Applied Physics". These certificates, of two grades, ordinary and higher, were first awarded in 1947, and are intended to provide training for, and a regular means of entry into, the profession of 'engineer-physicist' as an alternative to the conventional academic route. A helpful introduction to this discussion had been provided by the assistant secretary of the Institute of Physics, Mr. N. Clarke, who had circulated to members of the conference copies of his paper on the Institute's educational activities ${ }^{1}$, in which the present position is described. Mr. Robson outlined the courses and syllabus followed at the South-East London Technical College, where at present 118 day and 66 evening students are preparing for the Ordinary Certificate. Points raised in the discussion were: the difficulty of organising such courses in smaller technical colleges remote from any large industrial centre, the problem of examination standards, and the unsatisfactory nature of the conventional type of practical examination.

On the second day, with Dr. H. Lowery in the chair, Dr. G. van Praagh gave a paper on the "Teaching of Physics in Secondary Schools", and described the equipment and curriculum at Christ's Hospital, giving some details of the teaching carried on under almost ideal conditions in the appropriately named "Science Workshops" there. Sir Graham Savage opened the discussion by remarking on the importance of training the young to use their hands and their powers of observation, and also said that valuable contributions to the teaching of the subject could be made by men of enthusiasm who were not primarily qualified as physics specialists. Most of the schoolmasters present contributed accounts of their own methods of selecting material or adapting its presentation in such a way as to develop the pupils' enterprise and judgment. The discussion centred around the spirit in which the subject should be approached. Some speakers considered that examin. ation syllabuses might well be pruned; but little was said on the almost exhausted topic of examin. ations themselves.

Wing-Commander R. E. Burnett, of the Ministry of Labour, speaking on "Careers in Physics", said that while only the high-honours graduate should contemplate a research career, there was a need for many men with other gifts on the purely technical side of industry, and employers should be educated not to demand high academic qualifications for jobs where they are not essential. About eight hundred physics graduates are required annually, half of them for teaching, and at present some seven hundred are being trained. There is a very great shortage at present of people interested in 'classical' physics.

Mr. F. Bray (Under-Secretary, Ministry of Education) took the chair for the third day's session. 